\title{
Optimal enzymatic hydrolysis conditions for increased production of L-arginine and GABA in Dendropanax morbifera Lev. leaves
}

\author{
Ki Hoon Lee, Sunoh Kim* \\ B\&Tech Co., Ltd., R\&D Center, Gwangju 61239, Korea
}

\section{L-arginine과 GABA 함량 증가를 위한 황칠나무 잎의 적정 효소가수분해 조건}

\author{
이기훈 · 김선오* \\ (주)비엔텍 중앙연구원
}

\begin{abstract}
Dendropanax morbifera Lev. (DP) leaves have the potential for use as a functional food ingredient. In this study, D. morbifera Lev. leaves were subjected to enzymatic hydrolysis by proteinase, peptidase, trypsin, bromelain, and papain to increase L-arginine and $\gamma$-aminobutyric acid (GABA) levels. Hydrolysis time, temperature, $\mathrm{pH}$, vacuum conditions, enzyme type, enzyme concentration, and the order of enzyme administration were optimized to increase $L$-arginine and GABA concentrations. $L$-arginine and GABA recoveries were higher when enzymatic treatment was performed prior to the extraction process. No significant changes in L-arginine and GABA production were observed with changes in $\mathrm{pH}$, vacuum conditions, or enzyme concentration. The optimized procedure for obtaining the highest $L$-arginine and GABA concentrations was to inactivate the enzymes after $8 \mathrm{~h}$ of hydrolysis, extract the leaves, and to perform a second hydrolysis step at $16 \mathrm{~h}$ with proteinase, trypsin, bromelain, and papain. By increasing L-arginine and GABA levels simultaneously, high-quality hydrolyzed D. morbifera Lev. extract (Hy-DP) was produced efficiently in large quantities at a low cost. With this enzymatic treatment and extraction process, Hy-DP has the potential for use as a functional food ingredient. Further evaluation of $\mathrm{Hy}$-DP as a functional food additive may allow it to be used in foods.
\end{abstract}

Key words : Dendropanax morbifera Lev., L-arginine, $\gamma$-aminobutyric acid (GABA), enzymatic hydrolysis, optimization

\section{서 론}

서구형 식생활 패턴으로의 변화와 과잉 영양 섭취, 환경 오염, 운동부족 등의 원인으로 현대인들의 각종 성인병 발 병 증가는 심각한 사회적 문제가 되고 있다. 따라서 다양한 천연유래 식품소재가 가지고 있는 생리활성물질을 이용하 여 질병을 예방할 수 있는 건강기능식품을 개발하기 위한

*Corresponding author. E-mail : sunoh@korea.ac.kr Phone : 82-62-528-2201, Fax : 82-62-528-2202

Received 26 March 2019; Revised 15 April 2019; Accepted 15 April 2019.

Copyright (c) The Korean Society of Food Preservation. All rights reserved.
연구가 활발히 진행되고 있다. 특히 식물 추출물을 이용하 여 제조되는 건강기능식품들은 많은 생리활성물질들을 함 유하고 있어 신진대사 기능을 촉진하고 다양한 질병에 대한 예방효과가 크므로 그 수요가 급증하는 추세이며 시장규모 또한 확대되고 있는 실정이다(1).

황칠나무(Dendropanax morbifera Lev.)는 두릅나무과에 속하는 상록 활엽수로 제주도, 완도, 강진, 보길도 등 서남해 안 지역 및 일부 온대지역에서 자생하는 수종이다(2). 황칠 나무는 약 $15 \mathrm{~m}$ 정도 자라고 줄기는 흑갈색을 띄며 작은 가지는 녹색을 띈다. 황칠나무의 효능으로는 항염증, 항산 화, 항암, 항혈전증 등이 보고되어 있으며(3), 황칠수액의 주요 성분은 정유 성분으로서 sesquiterpene인 $\beta$-selinene, $\beta$-cubebene, $\beta$-elemene, germacrene $\mathrm{D}, \gamma$-cadinene 등 $(2,4,5)$ 
과 rutin, chlorogenic acid, (+)-catechin, ferulic acid, myricetin, quercetin, resveratrol 등의 페놀성 화합물(3)이 있다. 특히 우리의 선행연구를 통해 황칠나무의 부위별, 수확시기별, 추출용매별 quercetin의 함량 차이를 비교 분석 하고 표준 분석법을 확립하였다(6). 그 외 황칠나무의 성분 으로서 비타민, 유리당, 지방산, 아미노산 및 무기물 등의 성분 연구들이 진행되고 있으며 특히, 황칠나무 잎에는 유 리 아미노산 중 L-arginine의 함량이 다른 아미노산에 비해 매우 높은 비율로 구성되어 있다고 보고되고 있다(7). 최근 황칠나무의 효능이 널리 알려지면서 황칠나무를 활용한 가공제품이 다양하게 개발되고 있으며 건강기능식품 소재 로 활용하기 위한 연구도 많이 이루어지고 있다. 황칠나무 를 식품으로 가공하는 대표적인 방법은 황칠나무의 유용한 성분들을 물로 추출하여 음료나 차로 마시는 것이 대부분이 다. 그러나 자연 상태의 황칠나무 잎에 다량 존재하는 L-arginine을 포함한 기능성 아미노산을 최적 조건으로 추 출하는 공정에 대한 연구는 전무하며 현재는 전통적인 열수 추출법에 의존하고 있는 실정이다.

아미노산은 생물을 구성하는 중요한 단백질 구성 인자이 며 원활한 신진대사를 위해 절대적으로 필요한 영양소이 다. 아미노산의 다양한 기능성에 대한 활발한 연구와 함께 제약 산업뿐만 아니라 식품산업 분야에서도 소비자들의 관심이 증가되고 있으며 미국, 일본 등 여러 나라에서는 이미 기능성 식품소재로서 아미노산이 크게 성장하고 있는 실정이다(8). 아미노산은 필수 아미노산과 비 필수 아미노 산으로 나눌 수 있으며 필수 아미노산은 체내에서 합성되지 않지만 중요한 생리적 기능을 갖기 때문에 반드시 음식으로 공급해야만 한다. L-arginine은 조건부 필수 아미노산으로 서 혈관이완 물질인 산화질소(nitric oxide) 합성의 전구물질 로 작용하여 혈관이완에 도움을 주며 고혈압 등 혈관질환의 예방 및 치료를 위한 주요 기능성 물질로 널리 사용되고 있다(9). 또한 골밀도 감소지연, 성기능 개선, 체지방 감소 등 다양한 생리활성이 보고되고 있다(10-12). $\gamma$-Aminobutyric $\operatorname{Acid}(\mathrm{GABA})$ 는 비단백질 아미노산의 일종으로 중추신경 계에서 억제성 신경전달물질로 작용한다(13). 이러한 $\mathrm{GABA}$ 는 뇌의 골수에 대부분 존재하며 아세틸콜린이라 불리는 신경전달 물질을 증가시켜 뇌기능을 촉진하는 주요 한 물질로서, 혈압강하, 불안, 불면, 우울증, 통증 완화 등과 같은 기능성(14-16)과 지방대사 및 간 기능을 부분적으로 개선시켰다는 연구가 보고되었다(17). 즉 $\mathrm{L}$-arginine과 $\mathrm{GABA}$ 의 공통된 기능성으로 혈관 이완을 통한 혈압 강하 효과 및 혈행개선에 도움을 주는 기능을 갖고 있다.

황칠나무 잎에 함유되어 있는 유리아미노산은 15 종이 보고되었고 봄철에 채취한 황칠나무 잎에서 가장 많은 유리 아미노산이 함유되어 있다(7). 또한 이 연구의 보고에 따르 면 aspartic acid, glutamic acid 및 L-arginine의 함량이 상대 적으로 많았으며 그 중 L-arginine이 가장 높은 함량을 보였
고, 봄철에 채취한 황칠나무 잎에서 그 함량이 가장 높은 것으로 보고되었다. 그러나 연구에 사용된 황칠나무 시료 의 계절별 차이만 연구하였고, 이를 추출하는 조건 및 최적 추출을 위한 조건 확립에 대한 연구는 진행되지 않았다.

최근 대두, 인삼 및 천마 등의 단백질이 풍부한 식품 소재 를 활용하여 이용가치와 이용도를 증대시키기 위하여 물리 적, 화학적 또는 효소적 처리에 의한 단백질의 구조적 변화 를 일으키는 연구와 개발이 시도되고 있다 $(18,19)$. 그러나 단백질의 가수분해 방법으로 산 알칼리를 이용한 가수분해 가 주로 사용되고 있지만, 반응 생성물의 이미 이취가 발생 하고 함황아미노산의 손실 및 독성 물질의 형성 등을 초래 하여 단백질의 이용이 제한되고 있다(18). 그에 반해 효소적 가수분해방법은 용해도를 증가시키고 이취 성분을 유리시 키는 장점이 있으며, 영양성분의 손실을 방지할 수 있어 그 자체에 안전성이 부여되기 때문에 단백질 분해효소를 이용한 방법이 최근 많이 사용되고 있다(18).

따라서 본 연구에서는 황칠나무를 이용하여 기능성 식품 소재로써의 활용가능성을 확인하기 위한 연구의 일환으로 가수분해효소를 이용한 최적가수분해 공정을 개발하고 황 칠나무에 다량 함유되어 있는 유리아미노산 뿐만 아니라, 황칠나무의 단백질을 가수분해하여 다양한 기능성은 갖는 $\mathrm{L}-$ arginine과 $\mathrm{GABA}$ 의 최적화 추출 조건을 탐색하자 하였 다. 또한 두 가지 아미노산을 한 가지 공정을 통해 동시에 처리 할 수 있는 대량 생산 공정을 개발하고자 하였다.

\section{재료 및 방법}

\section{재 료}

본 실험에서 사용한 황칠나무는 전라남도 강진군 칠량면 에서 2017년에 재배된 8년생 이상의 것으로 3월-4월에 채취 한 잎을 사용하였다. 채취한 황칠나무 잎을 세척 후 1.5 $\mathrm{cm}$ 내외로 세절하였으며, 열 풍건조기(CF-21WF, Jeiotech, Daejeon, Korea)에서 건조 $\left(45^{\circ} \mathrm{C}, 24\right.$ 시간 $)$ 한 후 밀봉하여 보 관하면서 연구에 사용하였다. 황칠나무 잎을 가수분해하기 위하여 사용한 단백질가수분해효소인 Bacillus subtillis유 래 protease, trypsin, trypsin/chymotrypsin mixture, pepsin, ficin, bromelain 및 papain은 지니어텍 인터내셔날(Suwon, Korea)에서 구입하여 사용하였다. 분석 및 추출조건에서 사용된 시약은 Sigma-Aldrich Co.(St. Louis, MO, USA)의 특급 시약과 HPLC 등급을 구입하여 사용하였다.

\section{선 추출 후 가수분해 처리}

건조 세절한 황칠나무 잎 $1 \mathrm{~kg}$ 에 중량 대비 $1: 20(\mathrm{w} / \mathrm{v})$ 의 증류수를 첨가하고 $100^{\circ} \mathrm{C}$ 에서 4시간동안 초고속 진공저온 농축추출기(Cosmos660, Kyungseo machine, Incheon, Korea) 를 이용하여 열수 추출을 실시하였다. 이 추출물을 $30{ }^{\circ} \mathrm{Brix}$ 
로 농축하고 동결건조 시킨 후 분말로 제조하고 밀봉하여 냉암소에 보관하면서 모든 실험의 대조군(CTL)으로 사용 하였다. 추출 후 추출물의 온도가 $40^{\circ} \mathrm{C}$ 로 되었을 때 황칠나 무 잎 $1 \mathrm{~kg}$ 중량을 기준으로 Table 1 과 같은 다양한 조건의 함량으로 protease, trypsin/chymotrypsin mixture 또는 pepsin 을 첨가하고 교반기를 이용하여 $40^{\circ} \mathrm{C}$ 에서 4 8시간 동안 1 차 가수분해를 실시하였다. 1 차 가수분해 종료 후 황칠나 무 잎 $1 \mathrm{~kg}$ 중량을 기준으로 Table 1 과 같은 다양한 조건의 함량으로 bromelain과 papain 또는 ficin을 첨가하고 $50^{\circ} \mathrm{C}$ 에 서 12 16시간 2 차 가수분해를 실시하였다. 총 6 가지의 다른 조건으로 2 차 가수분해 종료 후 $100^{\circ} \mathrm{C}$ 에서 30 분간 효소 불활성화 과정을 거친 후 $30{ }^{\circ} \mathrm{Brix}$ 로 농축하고 동결건조 하여 분말화 하였다. 제조된 분말을 밀봉하여 냉암소에 보 관하면서 실험에 사용하였다. 총 6가지 각 조건별(A-F) 효 소 함량 및 가수분해 시간은 Table 1 과 같다.

\section{선 가수분해 처리 후 추출}

건조 세절한 황칠나무 잎 $1 \mathrm{~kg}$ 에 중량 대비 $1: 8(\mathrm{w} / \mathrm{v})$ 의 증류수를 첨가하고 $45^{\circ} \mathrm{C}$ 에서 4 시간 동안 초고속 진공저온 농축추출기(Cosmos660, Kyungseo machine)를 이용하여 침 지를 실시하였다. 침지 후 황칠나무 잎 $1 \mathrm{~kg}$ 에 중량 대비 $1: 1(\mathrm{w} / \mathrm{v})$ 의 증류수에 황칠나무 잎 $1 \mathrm{~kg}$ 중량을 기준으로 protease $1 \mathrm{~g}$, trypsin $1 \mathrm{~g}$ 을 녹여 효소액을 제조하여 침지액에 첨가하고 $45^{\circ} \mathrm{C}$ 에서 4 시간동안 1 차 가수분해를 실시하였다. 1 차 가수분해 종료 후 황칠나무 잎 $1 \mathrm{~kg}$ 에 중량 대비
$1: 1(\mathrm{w} / \mathrm{v})$ 의 증류수에 황칠나무 잎 $1 \mathrm{~kg}$ 중량을 기준으로 bromelain $1 \mathrm{~g}$, papain $1 \mathrm{~g}$ 을 녹여 효소액을 제조하여 첨가하 고 $55^{\circ} \mathrm{C}$ 에서 16 시간동안 2 차 가수분해를 실시하였다. 2 차 가수분해물을 $30{ }^{\circ} \mathrm{Brix}$ 로 농축하고 동결건조 시킨 후 분말 로 제조한 시표를 조건 $\mathrm{G}$ 로 하였다. 2 차 가수분해 종료 후 최종적으로 황칠나무 잎 $1 \mathrm{~kg}$ 에 중량 대비 $1: 10(\mathrm{w} / \mathrm{v})$ 의 증류수를 추가하여 $100^{\circ} \mathrm{C}$ 에서 4 시간동안 추출하는 동시에 효소불활성화를 수행 후 $30{ }^{\circ} \mathrm{Brix}$ 로 농축하고 동결건조 시 킨 후 분말로 제조한 시표를 조건 $\mathrm{H}$ 로 하였다. 1 차 가수분해 시 $5 \mathrm{~N} \mathrm{NaOH}$ 용액을 이용하여 $\mathrm{pH}$ 7.5로 조절하여 가수분해 를 실시하고, 2 차 가수분해 시 $10 \%(\mathrm{w} / \mathrm{v})$ citric acid 용액을 이용해 $\mathrm{pH} 5.5$ 로 조절하여 가수분해를 실시하였다. 이러한 조건의 2 차 가수분해물을 $30^{\circ} \mathrm{Brix}$ 로 농축하고 동결건조 시킨 후 분말로 제조한 시표를 조건 I로하고, 조건 I의 2차 가수분해물을 조건 $\mathrm{H}$ 와 동일한 방법으로 추출한 후 농축 및 동결건조를 수행한 시료를 조건 $\mathrm{J}$ 로 하였다. 최적 조건 $\mathrm{K}$ 의 제조는 Fig. 1 과 같이 건조 세절한 황칠나무 잎 $1 \mathrm{~kg}$ 에 중량 대비 $1: 9(\mathrm{w} / \mathrm{v})$ 의 증류수에 황칠나무 잎 $1 \mathrm{~kg}$ 중량 대비 $1: 0.002(\mathrm{w} / \mathrm{w})$ 의 효소 혼합물(protease $1 \mathrm{~g}$, trypsin $1 \mathrm{~g}$ )을 첨가하고 $45^{\circ} \mathrm{C}$ 에서 8 시간동안 침지 및 1 차 가수분해를 동시 에 실시하였다. 1 차 가수분해 종료 후 2 차 가수분해 및 추출 과정은 조건 $\mathrm{H}$ 와 동일하게 진행하였다. 조건 $\mathrm{L}$ 의 제조는 조건 $\mathrm{K}$ 와 동일하게 1 차 및 2 차 가수분해를 실시하였고, 2 차 가수분해 시 혐기성 조건을 조성하기 위해 진공을 300 torr 조건으로 설정하여 2차 가수분해를 실시하였다. 2차

Table 1. Pre-extraction and post-hydrolysis of Dendropanax morbifera Lev. leaf with different reaction time and enzyme contents

\begin{tabular}{|c|c|c|c|c|c|c|c|c|}
\hline \multirow{2}{*}{ Condition } & \multicolumn{4}{|c|}{ 1st. hydrolysis } & \multicolumn{4}{|c|}{ 2nd. hydrolysis } \\
\hline & protease $(\mathrm{g})$ & mixture $^{1)}(\mathrm{g})$ & pepsin $(g)$ & time (h) & bromelain (g) & papain (g) & ficin (g) & time (h) \\
\hline A & 1 & 1 & - & 4 & 1 & 1 & - & 16 \\
\hline B & 1 & 1 & 1 & 4 & 1 & 1 & 1 & 16 \\
\hline $\mathrm{C}$ & 1 & 1 & 1 & 6 & 1 & 1 & 1 & 14 \\
\hline $\mathrm{D}$ & 1 & 1 & 1 & 8 & 1 & 1 & 1 & 12 \\
\hline E & 2 & 1 & 1 & 4 & 1 & 1 & 1 & 16 \\
\hline $\mathrm{F}$ & 4 & 1 & 1 & 4 & 1 & 1 & 1 & 16 \\
\hline
\end{tabular}

${ }^{1)}$ trypsin/chymotrypsin mixture

Table 2. Pre-hydrolysis and post-extraction of Dendropanax morbifera Lev. leaf with different reaction time and enzyme contents

\begin{tabular}{|c|c|c|c|c|c|c|c|c|c|c|}
\hline \multirow{2}{*}{ Condition } & \multicolumn{4}{|c|}{ 1st. hydrolysis } & \multicolumn{5}{|c|}{ 2nd. hydrolysis } & \multirow{2}{*}{$\begin{array}{l}\text { extraction } \\
\text { time (h) }\end{array}$} \\
\hline & protease $(\mathrm{g})$ & trypsin $(\mathrm{g})$ & time (h) & $\mathrm{pH}$ & bromelain $(\mathrm{g})$ & papain (g) & time (h) & $\mathrm{pH}$ & vacuum (torr) & \\
\hline G & 1 & 1 & 4 & - & 1 & 1 & 16 & - & - & 0 \\
\hline $\mathrm{H}$ & 1 & 1 & 4 & - & 1 & 1 & 16 & - & - & 4 \\
\hline I & 1 & 1 & 4 & 7.5 & 1 & 1 & 16 & 5.5 & - & 0 \\
\hline $\mathrm{J}$ & 1 & 1 & 4 & 7.5 & 1 & 1 & 16 & 5.5 & - & 4 \\
\hline K & 1 & 1 & 8 & - & 1 & 1 & 16 & - & - & 4 \\
\hline $\mathrm{L}$ & 1 & 1 & 8 & - & 1 & 1 & 16 & - & 300 & 4 \\
\hline
\end{tabular}


가수분해 종료 후 추출 및 농축단계는 조건 $\mathrm{H}$ 와 동일하게 진행하였다. 총 6 가지 각 조건별(G-L) 효소 함량 및 가수분 해 시간은 Table 2와 같다.

\section{최적조건을 이용한 Pilot 규모 추출}

조건 $\mathrm{K}$ 의 가수분해 및 추출조건을 2 톤 규모의 추출기를 이용하여 pilot 규모에서의 시험생산을 다음과 같이 실시하 였다. 건조 세절한 황칠나무 잎 $80 \mathrm{~kg}$ 에 중량 대비 $1: 9(\mathrm{w} / \mathrm{v})$ 의 증류수 $(720 \mathrm{~L})$ 에 황칠나무 잎 $80 \mathrm{~kg}$ 중량 대비 $1: 0.002(\mathrm{w} / \mathrm{w})$ 의 효소 혼합물(protease $80 \mathrm{~g}$, trypsin $80 \mathrm{~g}$ )을 투입하여 효소액을 만들었다. 효소액 투입 후 $45^{\circ} \mathrm{C}$ 에서 8 시 간동안 처리하여 침지 및 1 차 가수분해를 동시에 실시하였 다. 1 차 가수분해 종료 후 황칠나무 잎 $80 \mathrm{~kg}$ 중량 대비 $1: 0.002(\mathrm{w} / \mathrm{w})$ 의 효소 혼합물(bromelain $80 \mathrm{~g}$, papain $80 \mathrm{~g}$ )을 별도의 증류수 $100 \mathrm{~L}$ 에 투입하여 효소액을 만들어 1 차 가수 분해물에 첨가하고 $55^{\circ} \mathrm{C}$ 에서 16 시간동안 2 차 가수분해를 실시하였다. 2 차 가수분해 종료 후 최종적으로 증류수 800 $\mathrm{L}$ 를 첨가하고 $100^{\circ} \mathrm{C}$ 에서 4 시간 동안 추출 및 효소불활성화 를 실시하였으며, $30{ }^{\circ} \mathrm{Brix}$ 로 농축하고 동결건조 분말로 최종 시료화 하였다.

\section{가수분해 추출물의 가용성 고형분 함량 측정}

각 조건별 가수분해 추출물의 가용성 고형분 함량은 식 품공전(20)에 준하여 실시하였다. 각 가수분해물을 동결건 조한 후 중량법에 따라 그 무게를 3회 반복 측정하였으며, 가수분해 추출물의 조제에 사용된 황칠나무 건물 시료량에 대한 백분율로써 가용성 고형분 함량을 표시하였다.

\section{단백질 함량 및 가수분해도 측정}

선정된 최적조건 (조건 $\mathrm{K}$ )을 대상으로 효소가수분해 전 과 효소가수분해 후의 가용성 단백질의 함량은 BSA(bovine serum albumin)를 표준물질로 하여 Bradford 방법으로 작성 한 표준곡선에 따라 단백질 정량하였다. 가수분해도(degree of hydrolysis)는 Park과 Yoon(21)의 방법에 따라 제조한 가수분해물에 동량의 $20 \% \mathrm{TCA}$ (trichloroacetic acid) 용액 을 넣어 $10 \% \mathrm{TCA}$ 가용성 단백질을 얻은 후 이를 $1,600 \times \mathrm{g}$ 로 30 분간 원심분리하고 상층액의 단백질 함량을 측정하여 다음과 같은 식에 의해 산출하였고, 황칠나무 잎을 첨가하 지 않고 동일 조건으로 효소만 처리하여 제조한 효소가수분 해물의 측정값을 기저치로 하여 기저치를 차감한 값을 사용 하였다.

$$
\text { 가수분해도 }(\%)=\frac{10 \% \text { TCA soluble protein }}{\text { Total protein }} \times 100
$$

아미노산 함량 분석

L-Arginine과 GABA를 포함하여 유리 아미노산의 분석
은 최종 동결건조한 분말을 이용하여 $\operatorname{Kim}$ 과 $\operatorname{Chung}(7)$ 의 방법을 활용하여 측정하였으며 분석조건은 Table 3 과 같다. HPLC는 Waters 510 pump, Waters Gradient Controller, Waters 717 Automatic sampler 및 Waters 2487 UV detector(Waters HPLC system, Millford, MA, USA)를 사용 하였고, 데이터 수집 및 처리를 위해 Empower2 software program(Waters Corporation, Milford, MA, USA)을 사용하 였다. 분석용 컬럼은 Waters Pico-tag column $(3.9 \times 300 \mathrm{~mm}$, $4 \mu \mathrm{m}$, Waters, Milford, MA, USA)을 사용하였으며, 이동상 용매 $\mathrm{A}$ 는 $6 \%$ acetonitrile이 함유된 $140 \mathrm{mM}$ sodium acetate 를, 용매 B는 $60 \%$ acetonitrile를 사용하여 $1.0 \mathrm{~mL} / \mathrm{min}$ 의 유속으로 각각 분석하였다. UV는 $254 \mathrm{~nm}$ 파장에서 측정하 였고, 시료 주입량은 $10 \mu \mathrm{L}$ 로 하였다.

\section{통계 분석}

본 실험은 독립적으로 3회 이상 반복 실시하여 실험결과 를 평균과 표준편차 $(m e a n \pm \mathrm{SD})$ 로 나타내었고, 통계분석은 Statistical Analysis System (SAS) 통계 프로그램을 이용하 여 각각 일원배치분산분석(One-way ANOVA Test)을 하고 Duncan's multiple range test와 t-test로 유의성 검정을 실시 하였다.

Table 3. Analytical condition of HPLC for analysis of L-arginine and GABA.

\begin{tabular}{|c|c|c|c|}
\hline Parameters & \multicolumn{3}{|c|}{ Condition } \\
\hline Column & \multicolumn{3}{|c|}{ Waters Pico-tag column $(3.9 \times 300 \mathrm{~mm}, 4 \mu \mathrm{m})$} \\
\hline Detector & \multicolumn{3}{|c|}{ UV $254 \mathrm{~nm}$} \\
\hline Flow rate & \multicolumn{3}{|c|}{$1.0 \mathrm{~mL} / \mathrm{min}$} \\
\hline Column temperature & \multicolumn{3}{|c|}{$40^{\circ} \mathrm{C}$} \\
\hline Injection volume & \multicolumn{3}{|c|}{$10 \mu \mathrm{L}$} \\
\hline Mobile phase & \multicolumn{3}{|c|}{$\begin{array}{l}\text { A: } 140 \mathrm{mM} \text { sodium acetate in } 6 \% \text { acetonitrile } \\
\text { B: } 60 \% \text { acetonitrile }\end{array}$} \\
\hline \multirow{9}{*}{ Gradient } & Time (min) & $\mathrm{A}(\%)$ & $\mathrm{B}(\%)$ \\
\hline & 0 & 100 & 0 \\
\hline & 9.0 & 86 & 14 \\
\hline & 9.2 & 80 & 20 \\
\hline & 17.5 & 54 & 46 \\
\hline & 17.7 & 0 & 100 \\
\hline & 21.0 & 100 & 0 \\
\hline & 24.0 & 100 & 0 \\
\hline & 25.0 & 100 & 0 \\
\hline
\end{tabular}

\section{결과 및 고찰}

\section{황칠나무 잎 추출물의 유리아미노산 조성}

황칠나무 잎으로부터 기능성 아미노산이 가장 많이 생성 되는 가수분해물을 생산하기 위한 단백질 분해 효소와 처리 
조건을 확립하기 위해 먼저 일반적인 방법으로 추출한 황칠 나무 잎 열수추출물의 유리아미노산 분포와 함량을 측정해 보았다(Table 4). 20종의 아미노산이 검출되었는데 그 중에 서 alanine $(33.680 \mathrm{mg} / \mathrm{g})$, valine $(17.229 \mathrm{mg} / \mathrm{g})$, glutamic acid (15.655 mg/g), aspartic aicd (15.146 mg/g), GABA $(13.340 \mathrm{mg} / \mathrm{g})$, proline $(8.925 \mathrm{mg} / \mathrm{g})$ 및 asparagine $(8.682$ $\mathrm{mg} / \mathrm{g}$ )순으로 함량이 검출되었다. Kim과 Chung(7)이 보고 한 황칠나무 잎에 분포한 유리아미노산 분포량 보고와 비교 하였을 때 aspartic aicd (17.2 mg\%)와 glutamic acid (12.3 $\mathrm{mg} \%)$ 가 많이 검출된 부분에서는 유사하였으나 본 연구에 서는 L-arginine의 함량이 $2.903 \mathrm{mg} / \mathrm{g}$ 이 검출되어 다른 아미 노산에 비해 그 분포량이 높지 않았다. 그러나 함유량을 비교하였을 때에는 Kim과 Chung(7)이 보고한 L-arginine의 함량(37.2 mg\%)에 비해 본 실험에서는 약 7배가 높게 L-arginine이 함유되었음을 알 수 있었다. 이는 기존의 연구 에서 사용한 황칠나무의 수령이 명확하게 제시되어 있지 않았고, 채취한 지역이 상이하였으며 추출 및 농축 방법의 차이 등의 요인에 의한 차이로 사료된다. 또한 $\mathrm{GABA}$ 는 본 연구에서 최초로 황칠나무 잎에서 검출되어 황칠나무 잎에 GABA가 상당히 높은 수준으로 함유되어 있음을 알

Table 4. The free amino acid contents of Dendropanax morbifera Lev. leaf extracts

\begin{tabular}{|c|c|c|}
\hline \multicolumn{3}{|c|}{ Amino acid (mg/g) } \\
\hline 1 & Alanine & 33.680 \\
\hline 2 & Arginine & 2.903 \\
\hline 3 & Aspartic acid & 15.146 \\
\hline 4 & GABA & 13.340 \\
\hline 5 & Glutamic acid & 15.655 \\
\hline 6 & Glycine & 1.223 \\
\hline 7 & Histidine & 1.940 \\
\hline 8 & Leucine & 5.159 \\
\hline 9 & Isoleucine & 6.558 \\
\hline 10 & Lysine & 2.258 \\
\hline 11 & Methionine & 2.820 \\
\hline 12 & Phenylalanine & 1.439 \\
\hline 13 & Proline & 8.925 \\
\hline 14 & Serine & 6.025 \\
\hline 15 & Threonine & 2.853 \\
\hline 16 & Tryptophan & 0.444 \\
\hline 17 & Tyrosine & 7.501 \\
\hline 18 & Valine & 17.229 \\
\hline 19 & Asparagine & 8.682 \\
\hline 20 & Cystein & 2.537 \\
\hline \multirow[t]{2}{*}{21} & Glutamine & N.D. \\
\hline & Total & 156.317 \\
\hline
\end{tabular}

수 있었다. Jeoung 등(22)이 보고한 연구에 따르면 GABA함 량이 높다고 알려진 녹차잎 $(738.9 \mathrm{mg} \%)$, 미강 $(252.6 \mathrm{mg} \%)$, 및 거대미강 $(809.2 \mathrm{mg} \%)$ 과 비교하였을 때 본 연구에서 황 칠나무 잎에 함유된 $\mathrm{GABA}$ 는 최소 1.5 배에서 최대 5.3배 이상 높게 함유되어 있음을 알 수 있었다. 이는 황칠나무 잎에 함유된 L-arginine과 GABA는 섭취 시 생리활성 효과 를 나타낼 수 있는 충분한 양으로 사료되며 이러한 생리활 성 기능을 확대시키기 위해 그 함량을 증가시키는 공정 개발은 황칠나무 잎을 이용한 건강기능식품 소재로 개발하 는데 충분한 가치가 있을 것으로 사료된다.

\section{황칠나무 잎 가수분해처리를 통한 추출수율}

황칠나무 잎으로부터 최적 가수분해물을 생산하기 위한 단백질 분해 효소 종류와 효소처리조건을 확립하기 위해 총 12 가지 조건을 이용하여 효소 반응과 추출을 진행 후 이들의 가용성 고형분 함량 측정을 통해 추출수율을 측정 (Table 5)하였다. 단백질 분해 효소를 처리하지 않은 황칠나 무 잎의 열수 추출물을 기준으로 효소 종류, 가수분해 시간, 효소 농도 및 효소처리방법 등의 조건을 Table 1과 Table 2에 나타내었다. 단백질 분해 효소 처리조건별 및 추출조건 별 가용성 고형분 함량 변화는 일반 열수추출물과 비교하였 을 때 특별히 증가되거나 감소되는 경향은 보이지 않았다. 또한 단백질 분해 효소를 전처리 조건과 후처리 조건과 비교하였을 때에도 특별히 추출효율이 증가되는 경향은 보이지 않았다. 반면 조건 $\mathrm{G}$ 와 조건 $\mathrm{I}$ 의 경우 단백질 분해 효소 처리 후 추출공정을 진행하지 않는 조건의 경우에만 추출 수율이 다소 낮아지는 것을 알 수 있었다. 이러한 결과

Table 5. Yield of extracts obtained by hydrolysis and extraction of Dendropanax morbifera Lev. with different reaction time and enzyme contents

\begin{tabular}{cc}
\hline Condition & $\begin{array}{c}\text { Soluble solids } \\
\text { Yield (\%) }\end{array}$ \\
\hline CTL & 26.54 \\
A & 30.73 \\
B & 28.77 \\
C & 24.50 \\
D & 24.86 \\
E & 24.38 \\
F & 23.86 \\
G & 19.35 \\
H & 29.62 \\
I & 20.04 \\
J & 27.50 \\
K & 28.75 \\
L & 30.05 \\
\hline Pilot scale & 27.68 \\
\hline
\end{tabular}


로 본 연구에서 설정한 단백질 분해 효소 처리 및 추출공정 에 포함된 20 배수의 증류수로 $100^{\circ} \mathrm{C}$ 에서 4 시간동안 추출하 는 공정은 황칠나무에 존재하는 가용성 고형분 성분을 최대 한 추출할 수 있는 추출공정임을 알 수 있으며, 가용성 고형 분 추출수율의 효율증가 효과 보다는 단백질 분해 효소에 의한 기능성 성분의 전환에 따른 성분 함량 변화를 예측할 수 있을 것으로 사료된다.

\section{황칠나무 잎 최적 가수분해처리 방법}

각 12 가지 조건별 L-arginine과 $\mathrm{GABA}$ 의 함량 변화율을 비교해본 결과는 Table 6에 나타내었다. 열수추출을 진행한 후 단백질 분해 효소를 처리한 공정들(조건 A-F)에서는 L-arginine의 함량이 모든 공정에서 다소 감소하는 결과를 보였다. 그러나 $\mathrm{GABA}$ 의 경우는 모든 조건에서 함량이 증 가되는 것을 확인할 수 있었으며 조건 $\mathrm{F}$ 의 경우 최대 $149.74 \%$ 까지 GABA 함량이 증가되는 것을 확인 할 수 있었 다. 그러나 단백질 분해 효소처리의 농도, 시간 및 종류에 비례하여 특별한 경향을 보이며 함량이 증가되는 현상은 관찰 할 수 없었다.

다른 방법으로 1 차 단백질 분해 효소를 처리 시 건조된 황칠나무 잎을 4 시간 충분히 침지시킨 후 단백질 분해 효소 를 처리하고 열수추출과정을 진행한 공정들(조건 G-J)에서 는 L-arginine과 GABA의 함량 모두가 크게 증가되는 결과 를 보였다. 따라서 L-arginine과 $\mathrm{GABA}$ 의 함량을 증가시키 는 가장 중요한 공정은 단백질 분해 효소를 먼저 처리 한 후 추출과 효소불활성화 공정을 진행하는 것이 가장 효율적 인 공정임을 알 수 있었다. 이는 먼저 열수추출을 진행하였

Table 6. L-arginine and GABA contents in Dendropanax morbifera Lev. leaf extracts at different conditions of hydrolysis

\begin{tabular}{ccccc}
\hline Condition & $\begin{array}{c}\text { L-Arginine } \\
(\mathrm{mg} / \mathrm{g})\end{array}$ & $\begin{array}{c}\text { fold changes } \\
\text { from CTL }^{1)}\end{array}$ & $\begin{array}{c}\text { GABA } \\
(\mathrm{mg} / \mathrm{g})\end{array}$ & $\begin{array}{c}\text { fold changes } \\
\text { from CTL }^{1}\end{array}$ \\
\hline CTL & 2.903 & 0 & 13.340 & 0 \\
$\mathrm{~A}$ & 2.766 & 0.95 & 18.338 & 1.37 \\
$\mathrm{~B}$ & 2.544 & 0.88 & 18.310 & 1.37 \\
$\mathrm{C}$ & 2.335 & 0.80 & 19.095 & 1.43 \\
$\mathrm{D}$ & 2.361 & 0.81 & 19.401 & 1.45 \\
$\mathrm{E}$ & 2.383 & 0.82 & 17.009 & 1.28 \\
$\mathrm{~F}$ & 2.321 & 0.80 & 19.975 & 1.50 \\
\hline $\mathrm{G}$ & 6.653 & 2.29 & 18.411 & 1.38 \\
$\mathrm{H}$ & 7.685 & 2.65 & 18.017 & 1.35 \\
$\mathrm{I}$ & 6.513 & 2.24 & 20.580 & 1.54 \\
$\mathrm{~J}$ & 7.507 & 2.59 & 25.176 & 1.89 \\
$\mathrm{~K}$ & 18.730 & 6.45 & 30.450 & 2.28 \\
$\mathrm{~L}$ & 15.097 & 5.20 & 17.717 & 1.33 \\
\hline Pilot scale & 9.434 & 3.25 & 20.056 & 1.50 \\
\hline${ }^{1)}$ CTL(control) & Non-hydrolyzed & Dendropanax & morbifera Lev. extract \\
\hline
\end{tabular}

을 경우 고압과 고열에 의해 황칠나무 잎 단백질이 열변성 에 의해 단백질 분해 효소의 기질로서 적절하게 작용하지 못한 것으로 사료된다. 세부적인 여러 처리 조건들을 달리 하여 처리한 결과 단백질 분해 효소의 활성에 가장 적절하 다고 알려진 $\mathrm{pH}$ 조건을 조절한 공정에서도 L-arginine과 $\mathrm{GABA}$ 의 함량이 큰 폭으로 증가되었으나, $\mathrm{pH}$ 를 조절하지 않은 조건과 비교하였을 경우 큰 차이가 없음을 알 수 있었 다. 1 차 단백질 분해 효소를 처리 전 4 시간동안 건조된 황칠 나무 잎을 침지시킨 공정을 1 차 단백질 분해 효소를 포함하 여 8시간동안 침지 및 효소처리를 동시에 처리한 조건 $\mathrm{K}$ 에 서 L-arginine 함량 $18.730 \mathrm{mg} / \mathrm{g}$ 으로 $645.19 \%$ 로 가장 높게 증가되었으며, $\mathrm{GABA}$ 의 경우에도 $30.450 \mathrm{mg} / \mathrm{g}$ 으로 $228.26 \%$ 증가되었음을 알 수 있었다. 즉, 단백질 분해 효소 처리 과정을 거치지 않은 황칠나무 열수추출물이 조건 $\mathrm{K}$ 의 단백질 분해 효소 처리과정을 통해 L-arginine의 함량이 약 6.5 배 이상 증가하였고, $\mathrm{GABA}$ 의 함량이 약 2.3 배 이상 증가 함을 확인 할 수 있었다. Sawai 등(23)은 차나무 줄기와 잎을 혐기처리한 후 아미노산의 함량 변화 결과 혐기처리에 의해 $\mathrm{GABA}$ 의 함량이 증진되었다고 보고하였고, Pyo (24) 는 홍국균을 이용한 콩의 발효가 GABA와 유리아미노산 함량을 각각 최대 2.5 배와 5.6배 증가시킨다고 보고하였다. 또한 Jeon 등(25)의 연구에서 한약재 추출물을 발아수로 이용하고 열처리를 줌으로써 현미 발아 후 $\mathrm{GABA}$ 함량을 약 2.5배 증가시킨다고 보고하였다. 따라서 가장 L-arginine 과 $\mathrm{GABA}$ 의 함량이 증가된 조건과 동일한 조건에서 혐기성 환경에 의한 $\mathrm{GABA}$ 의 함량의 영향을 알아보기 위해 진공처 리 공정(조건 $\mathrm{L})$ 을 추가하였을 경우에는 $\mathrm{GABA}$ 의 함량 변 화는 크게 관찰되지 않았다. 결론적으로 L-arginine과 $\mathrm{GABA}$ 를 동시에 증가 시킬 수 있는 조건으로는 $\mathrm{pH}$, 혐기성 환경, 효소 첨가량, 종류 등에 대한 조건을 모두 단순화시키 며 침지와 1 차 단백질 분해 효소반응을 동시 진행 시킨 후 2차 단백질 분해 효소반응을 실시한 조건 $\mathrm{K}$ 를 최적 추출 조건으로 확립하였으며, 최적 공정 flow chart를 Fig. 1에 나타내었다. 이렇게 확립된 조건 $\mathrm{K}$ 의 방법으로 pilot 규모의

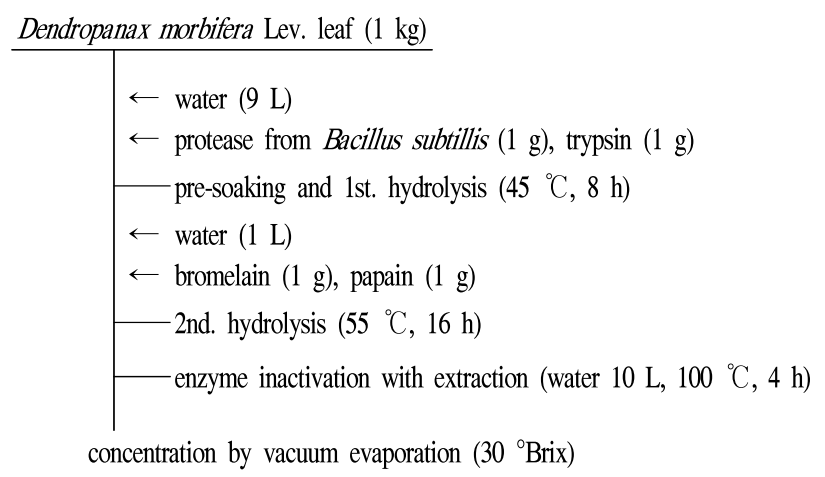

Fig. 1. Extraction process of Dendropanax morbifera Lev. leaf using enzymatic hydrolysis. 

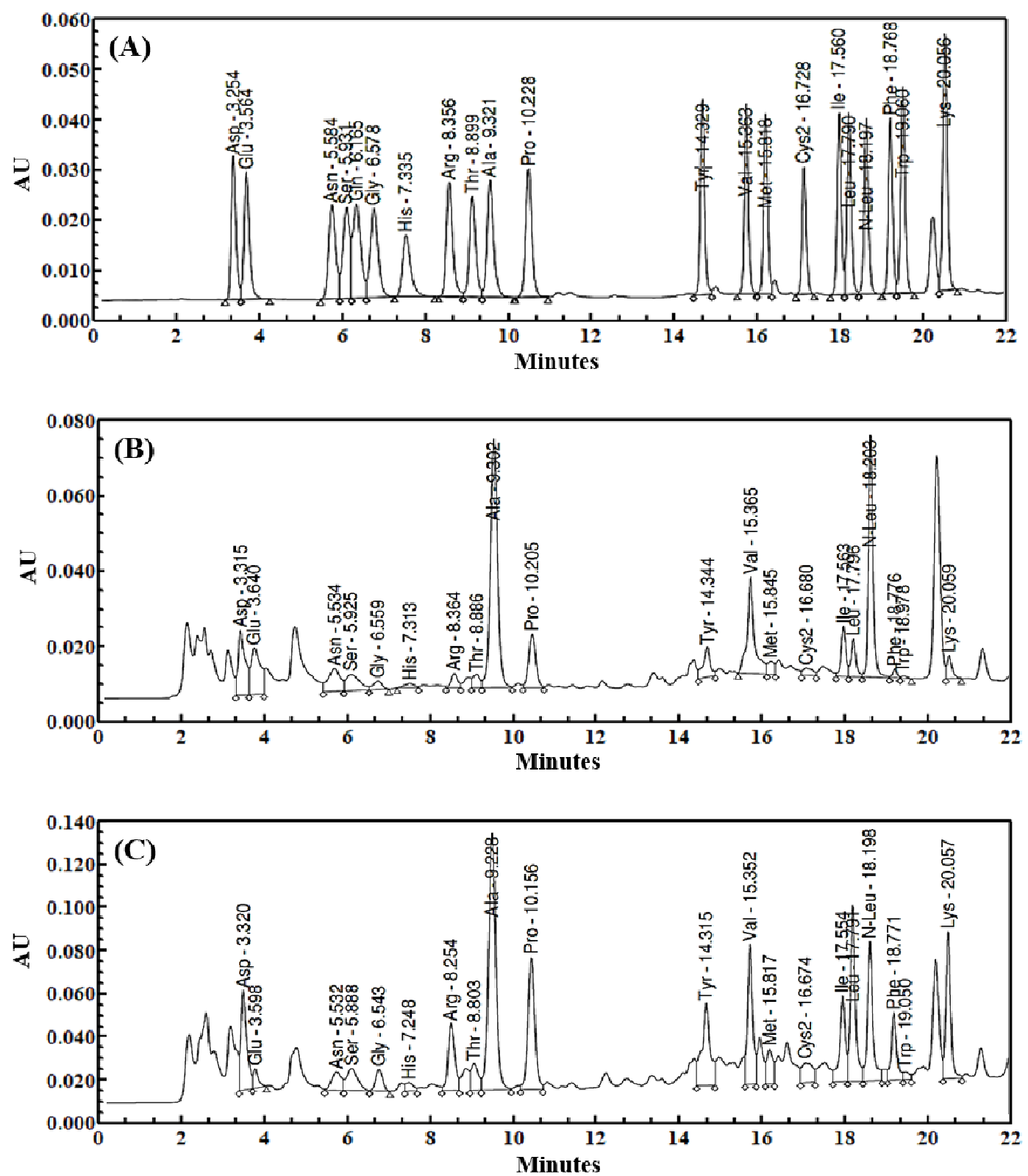

Fig. 2. Amino acids chromatogram profiles of (A) standards of amino acid, (B) water extract of Dendropanax morbifera Lev. leaf, and (C) condition $\mathrm{K}$ extract of Dendropanax morbifera Lev. leaf.

대형 추출기를 이용하여 단백질 분해 효소처리와 추출을 진행한 결과 L-arginine 함량은 $9.434 \mathrm{mg} / \mathrm{g}$ 으로 $324.97 \%$ 로 높게 증가되었으며, $\mathrm{GABA}$ 의 경우에도 $20.056 \mathrm{mg} / \mathrm{g}$ 으로 $150.34 \%$ 증가되었음을 알 수 있었다. 비록 소량 반응을 진행하였던 조건 $\mathrm{K}$ 보다는 낮은 증가 효율을 보였지만 $\mathrm{lab}$ scale의 다른 조건들의 결과보다는 높은 수준의 증가 효율 을 보였다. 이는 가온과 감온에 소요되는 기계적 특징 차이 에 따른 시간 차이와 같은 다양한 변수가 작용한 것이라고 판단된다. 따라서 향후 반복적이며 다양한 시설에서의 pilot 규모 시험에 대한 연구를 통해 scale up 공정을 확립할 필요 가 있을 것으로 사료된다.

\section{가수분해율 측정}

선정된 최적 가부분해 및 추출 조건을 이용하여 단백질 분해 효소 처리 전과 후의 단백질량과 가수분해율을 Table 7 에 나타내었다. 가수분해 전의 단백질량은 평균 $12.62 \pm 0.21$ $\mathrm{mg} / \mathrm{g}$ 이었으며, 단백질 분해 효소 처리 후의 단백질량은 평균 $2.04 \pm 0.25 \mathrm{mg} /$ 으로 약 $83.87 \pm 2.15 \%$ 의 단백질이 가수 분해 되었음을 알 수 있었다. Park과 Yoon(21)의 연구에서 는 들깨에서 단백질 가수분해물을 얻기 위해 flavourzyme 을 이용하여 가수분해한 결과 가수분해율이 $70.50 \%$ 로 가장 높았으며 본 연구결과와 비슷한 경향을 보였다. 

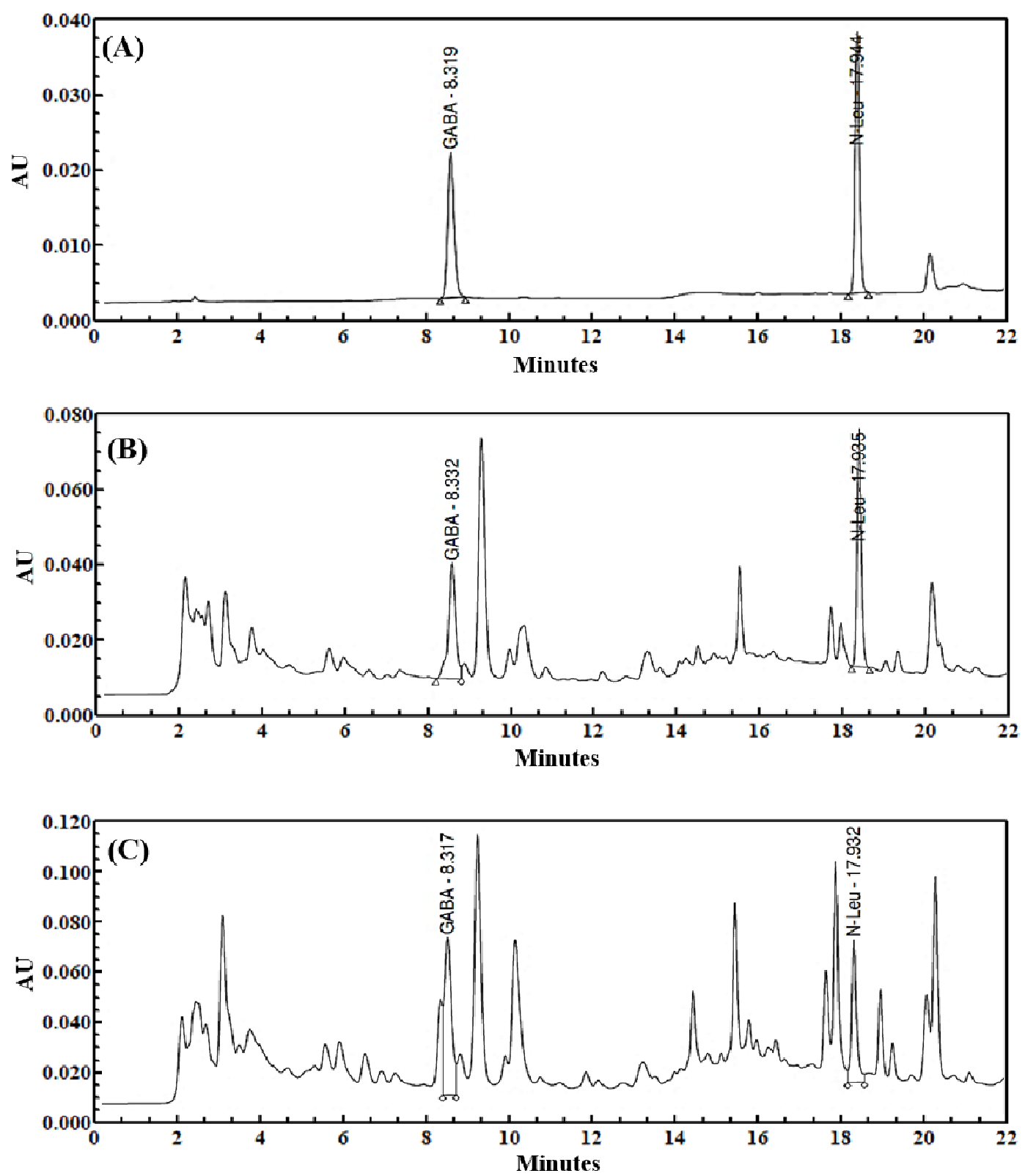

Fig. 3. GABA chromatogram profiles of (A) standard of GABA, (B) water extract of Dendropanax morbifera Lev. leaf, and (C) condition $\mathrm{K}$ extract of Dendropanax morbifera Lev. leaf.

Table 7. Degree of enzymatic hydrolysis of Dendropanax morbifera Lev. leaf extracts

\begin{tabular}{|c|c|c|c|c|}
\hline \multirow{2}{*}{\multicolumn{2}{|c|}{ Name of the extract }} & \multicolumn{2}{|c|}{ Protein (mg/g) } & \multirow{2}{*}{$\begin{array}{c}\text { Degree of } \\
\text { hydrolysis (\%) }\end{array}$} \\
\hline & & $\begin{array}{l}\text { Before enzyme } \\
\text { hydrolysis }\end{array}$ & $\begin{array}{l}\text { After enzyme } \\
\text { hydrolysis }\end{array}$ & \\
\hline \multirow{3}{*}{ Condition $\mathrm{K}$} & Sample 1 & 12.567 & 2.313 & 81.594 \\
\hline & Sample 2 & 12.400 & 2.091 & 83.134 \\
\hline & Sample 3 & 12.900 & 1.703 & 86.801 \\
\hline \multicolumn{2}{|c|}{ mean \pm SD } & $12.622 \pm 0.208$ & $2.036 \pm 0.252^{* * *}$ & $83.872 \pm 2.184$ \\
\hline
\end{tabular}

최적 가수분해물의 유리 아미노산 함량

황칠나무 잎 추출물, 조건 $\mathrm{K}$ 의 가수분해물 및 pilot 가수 분해물의 유리아미노산과 GABA의 HPLC chromatogram은 Fig. 2와 3에 나타내었고 그 함량과 분포를 Table 8 에 나타내 었다. L-arginine은 일반 열수추출물 $(2.61 \pm 1.02 \mathrm{mg} / \mathrm{g})$ 에 비 해 조건 $\mathrm{K}$ 에서 유의적으로 증가 $(17.77 \pm 1.36 \mathrm{mg} / \mathrm{g})$ 되었으며 pilot 규모에서도 유의적으로 증가 $(8.74 \pm 0.96 \mathrm{mg} / \mathrm{g})$ 되었다. GABA또한 일반 열수추출물 $(15.53 \pm 3.10 \mathrm{mg} / \mathrm{g})$ 에 비해 조 건 $\mathrm{K}$ 에서 유의적으로 증가 $(27.81 \pm 3.73 \mathrm{mg} / \mathrm{g})$ 되었으며 pilot 규모에서도 유의적으로 증가 $(20.28 \pm 0.43 \mathrm{mg} / \mathrm{g})$ 되었다. 
Table 8. The free amino acid contents of Dendropanax morbifera Lev. leaf extracts

\begin{tabular}{|c|c|c|c|c|}
\hline \multicolumn{2}{|c|}{ Amino acid (mg/g) } & \multirow{2}{*}{$\begin{array}{c}\text { CTL extracts }^{1)} \\
33.61 \pm 0.11\end{array}$} & \multirow{2}{*}{$\frac{\text { Optimal condition K extracts }}{40.41 \pm 7.31^{\text {N.S2) }}}$} & \multirow{2}{*}{$\begin{array}{c}\text { Pilot scale extracts } \\
29.42 \pm 1.13^{\text {N.S }}\end{array}$} \\
\hline 1 & Alanine & & & \\
\hline 2 & Arginine & $2.61 \pm 1.02$ & $17.77 \pm 1.36^{* * *}$ & $8.74 \pm 0.96^{* * *}$ \\
\hline 3 & Aspartic acid & $14.02 \pm 1.59$ & $19.72 \pm 1.75^{*}$ & $14.23 \pm 2.79^{\mathrm{N.S}}$ \\
\hline 4 & GABA & $15.53 \pm 3.10$ & $27.81 \pm 3.73^{* *}$ & $20.28 \pm 0.43^{*}$ \\
\hline 5 & Glutamic acid & $13.35 \pm 3.26$ & $3.01 \pm 0.46^{* * *}$ & $6.74 \pm 1.45^{* *}$ \\
\hline 6 & Glycine & $1.36 \pm 0.20$ & $2.96 \pm 0.76^{\text {N.S }}$ & $2.16 \pm 0.06^{\mathrm{NSS}}$ \\
\hline 7 & Histidine & $2.25 \pm 0.44$ & $3.84 \pm 1.01^{\mathrm{N} . \mathrm{S}}$ & $0.76 \pm 0.14^{*}$ \\
\hline 8 & Leucine & $4.99 \pm 0.24$ & $24.16 \pm 1.00^{* * *}$ & $10.73 \pm 0.10^{* *}$ \\
\hline 9 & Isoleucine & $6.36 \pm 0.29$ & $12.77 \pm 0.41^{* *}$ & $6.11 \pm 0.26^{\mathrm{N} . \mathrm{S}}$ \\
\hline 10 & Lysine & $2.00 \pm 0.37$ & $13.70 \pm 7.24^{* * *}$ & $9.64 \pm 0.71^{* *}$ \\
\hline 11 & Methionine & $1.83 \pm 1.40$ & $5.50 \pm 1.77^{* *}$ & $2.66 \pm 1.43^{\mathrm{N} . S}$ \\
\hline 12 & Phenylalanine & $1.46 \pm 0.03$ & $12.41 \pm 0.12^{* * *}$ & $5.00 \pm 0.25^{* *}$ \\
\hline 13 & Proline & $13.27 \pm 6.14$ & $21.12 \pm 0.24^{*}$ & $15.72 \pm 2.67^{\mathrm{N} . S}$ \\
\hline 14 & Serine & $6.18 \pm 0.22$ & $7.90 \pm 1.91^{\mathrm{N} . S}$ & $5.68 \pm 0.79^{\mathrm{N} . \mathrm{S}}$ \\
\hline 15 & Threonine & $3.34 \pm 0.69$ & $4.70 \pm 1.04^{\mathrm{N} . \mathrm{S}}$ & $3.16 \pm 1.50^{\mathrm{N} . \mathrm{S}}$ \\
\hline 16 & Tryptophan & $0.50 \pm 0.08$ & $0.87 \pm 1.24^{\mathrm{N} . \mathrm{S}}$ & N.D. \\
\hline 17 & Tyrosine & $9.78 \pm 3.22$ & $23.34 \pm 0.04^{*}$ & $15.82 \pm 0.34^{\mathrm{N} . S}$ \\
\hline 18 & Valine & $13.50 \pm 5.27$ & $18.04 \pm 1.71^{\mathrm{N} . S}$ & $13.32 \pm 4.12^{\mathrm{N} . \mathrm{S}}$ \\
\hline 19 & Asparagine & $8.02 \pm 0.94$ & $7.44 \pm 2.55^{\mathrm{N} . \mathrm{S}}$ & $6.44 \pm 0.55^{\mathrm{N} . \mathrm{S}}$ \\
\hline 20 & Cystein & $2.28 \pm 0.36$ & $5.30 \pm 3.08^{\mathrm{N} . \mathrm{S}}$ & $0.50 \pm 0.12^{*}$ \\
\hline \multirow[t]{2}{*}{21} & Glutamine & N.D. ${ }^{2)}$ & N.D. & N.D. \\
\hline & Total & 157.24 & 272.77 & 177.11 \\
\hline
\end{tabular}

Data are presented as mean \pm SD of triplicate measurements. ${ }^{\mathrm{N} . S} \mathrm{p}>0.05$ (N.S=not significant), ${ }^{*} \mathrm{p}<0.05,{ }^{* *} \mathrm{p}<0.01,{ }^{* * *} \mathrm{p}<0.001$.

${ }^{1)}$ CTL(control) : Non-hydrolyzed Dendropanax morbifera Lev. extract

${ }^{2)}$ N.D : Not detected

GABA는 glutamic acid의 탈탄산화에 의해 생성되는 중요 한 억제성 신경전달물질로서 흥분억제효과, 항경련작용, 정신집중력과 기억력 강화, 혈압강하 등의 체내 기능을 갖 는다(25). 본 실험결과에 따르면 $\mathrm{GABA}$ 의 함량이 증가될수 록 glutamic acid의 함량이 감소된 것으로 보아 단백질 분해 효소에 의해 증가된 $\mathrm{GABA}$ 는 황칠나무에 존재하는 glutamic acid의 탈탄산화 작용으로 증가된 것임을 알 수 있다. L-arginine과 GABA 이외에도 leucine, lysine 및 phenylalanine이 조건 $\mathrm{K}$ 와 pilot 조건 모두에서 상대적으로 함량이 증가되었음을 알 수 있었으며, aspartic acid, isoleucine, methionine, proline 및 tyrosine도 조건 $\mathrm{K}$ 에서 다 소 함량이 증가되었음을 알 수 있어 전체적으로 유리아미노 산의 함량이 증가되었음을 알 수 있었다.

이상의 분석결과, 단백질 분해 효소인 protease와 trypsin 을 처리한 후 침지와 1 차 가수분해를 8 시간 동시 진행하고, 이 후 bromelain과 papain을 추가하여 16시간 동안 2차 가수 분해를 실시하여 추출한 조건이 황칠나무의 기능성 아미노 산 중 하나인 L-arginine과 GABA를 동시 증가시킬 수 있는
최적 추출 공정으로 적용 가능함을 확인 할 수 있었다. 따라서 단백질 분해 효소를 이용한 가수분해 추출이 향후 황칠나무의 기능성식품소재로서의 개발 및 연구에 활용되 어질 것으로 기대한다.

\section{요 약}

본 연구에서는 황칠나무로부터 다양한 약리작용 및 생리 활성을 더욱 향상시킨 새로운 기능성식품소재로서의 개발 과 동시에 황칠나무 잎 유래 $\mathrm{L}$-arginine과 $\mathrm{GABA}$ 의 증가 추출 조건을 최적화하였다. 선 추출 후 단백질 분해 효소 처리 조건과 선 단백질 분해 효소 처리 후 추출 조건으로 나누어 진행하였으며, 효소 종류, 가수분해 시간, 효소 농도 및 효소처리방법 등을 달리하였다. 각 조건별 L-arginine과 $\mathrm{GABA}$ 의 함량을 비교 분석하여 최적 추출 조건을 최종 확인하였다. 물과 함께 원료 중량의 $0.2 \%$ 함량의 protease, trypsin을 처리하고 $45^{\circ} \mathrm{C}$ 에서 8 시간동안 침지 및 1 차 가수분 
해를 동시에 실시한 후 동량의 bromelain, papain을 별도의 물과 함께 $55^{\circ} \mathrm{C}$ 에서 16 시간동안 2 차 가수분해를 실시하고 최종적으로 $100^{\circ} \mathrm{C}$ 에서 4 시간동안 추출 및 효소불활성화를 수행하는 조건을 최적 추출 조건으로 확립하였다. 황칠나 무 유래 L-arginine은 기존 $2.61 \pm 1.02 \mathrm{mg} / \mathrm{g}$ 에서 $17.77 \pm 1.36$ $\mathrm{mg} / \mathrm{g}$ 으로, $\mathrm{GABA}$ 의 함량은 $15.53 \pm 3.10 \mathrm{mg} / \mathrm{g}$ 에서 $27.81 \pm$ $3.73 \mathrm{mg} / \mathrm{g}$ 으로 가장 효율적으로 증가하였으며 $83.872 \%$ 의 가수분해율을 얻을 수 있었다.

\section{감사의 글}

본 연구는 농림축산식품부의 재원으로 농림수산식품기 술기획평가원의 고부가가치식품기술개발사업 (316065-3 및 116032-3)의 지원을 받아 수행된 연구 결과이며, 이에 감사드립니다.

\section{References}

1. Sadaki O (1996) The development of functional foods and material. Bioindustry, 13, 44-50

2. Jeong BS, Jo JS, Pyo BS, Hwang B (1995) Studies on the distribution of Dendropanax morbifera and component analysis of the golden lacquer. Korean $\mathbf{J}$ Biotechnol Bioeng, 10, 393-400

3. Hyun TK, Ko YJ, Kim EH, Chung IM, Kim JS (2015) Anti-inflammatory activity and phenolic composition of Dendropanax morbifera leaf extracts. Ind Crops Prod, 74, 263-270

4. Lim KP, Chung WY (1998) Studies on the development of traditional Korean Golden Vamish(Hwngchil)(П) chemical composition and coating-oil characteristics of the exudates and bark-extractives of Hwangchil namu (Dendropanax morbifera Lev.). Mokchae Konghak, 26, 7-13

5. Ahn JC, Kim MY, Kim OT, Kim KS, Kim SH, Kim SH, Hwang B (2002) Selection of the high yield capacity of Hwangchil lacquer and identification of aromatic components in essential oil of Dendropanax morbifera Lev. Korean J Medicinal Crop Sci, 10, 126-131

6. Lee KH, Na HJ, Song CK, Kang SY, Kim S (2018) Quercetin quantification in a Jeju Dendropanax morbifera Lev. extract by varying different parts, harvest times, and extraction solvents. Korean J Food Preserv, $25,344-350$

7. Kim HR, Chung HJ (2000) Chemical characteristics of the leaves and the seeds of korea Dendropanax (Dendropanax morbifera Lev.). J Korean Soc Appl Biol Chem, 43, 63-66

8. Kim HB, Kim SL, Kang SW (2004) Varietal analysis and quantification of amino acid in mulberry fruits. Korea J Seric Sci, 46, 47-53

9. Siasos G, Tousoulis D, Vlachopoulos C, Antoniades C, Stefanadi E, Ioakeimidis N, Andreou I, Zisimos K, Papavassiliou AG, Stefanadis C (2008) Short-term treatment with $\mathrm{L}$-arginine prevents the smoking-induced impairment of endothelial function and vascular elastic properties in young individuals. Int $\mathrm{J}$ Cardiol, 126, 394-399

10. Choi MJ (2009) Effects of arginine supplementation on bone mineral density and bone markers in OVX rats. Korean J Nutr, 42, 309-317

11. Chen J, Wollman Y, Chernichovsky T, Iaina A, Sofer M, Matzkin H (1999) Effect of oral administration of high-dose nitric oxide donor L-arginine in men with organic erectile dysfunction: results of a double-blind, randomized, placebo-controlled study. BJU Int, 83, 269-273

12. Fu WJ, Haynes TE, Kohli R, Hu J, Shi W, Spencer TE, Carroll RJ, Meininger CJ, Wu G (2005) Dietary L-arginine supplementation reduces fat mass in Zucker diabetic fatty rats. J Nutr, 135, 714-721

13. Guin TWC, Bottiglieri T, Carter SO (2003) GABA, 8 -hydroxybutyric acid, and neurological disease. Ann Neurol, 54, 3-12

14. Wang HF, Tsai YS, Lin ML, Ou AS (2006) Comparison of bioactive components in GABA tea and green tea produced in Taiwan. Food Chem, 96, 648-653

15. Qingyun B, Meiqing C, Zhenxin G, Xiaohong C, Yan L, Kunlun L (2009) Effects of components in culuture medium on glutamate decarboxylase activity and $\mathrm{r}$ -aminobutyric acid accumulation in foxtail millet (Setaria italic L.) during germination. Food Chem, 116, 152-157

16. Bjork JM, Moeller FG, Kramer GL, Kram M, Suris A, Rush AJ, Petty F (2001) Plasma GABA levels correlate with aggressiveness in relatives of patients with unipolar depressive disorder. Psychiatry Res, 101, 131-136

17. Hwang ES, Jang MR, Kim GH (2012) Effects of storage condition on the bioactive compound contents of Korean cabbage. Food Sci Biotechnol, 21, 1655-1661

18. Lee MH, Gu YA, Choi MS, Kwon JH, Kim IS, Jeong YJ (2007) Characteristic changes in red ginseng fusion Cheonggukjang based on hydrolysis conditions. J Korean 
Soc Food Sci Nutr, 36, 1031-1037

19. Kim HT, Park EJ (2014) Change of amino acids contents of Gastrodia elata Blume with harvest times and seed tuber. J Plant Biotechnol, 41, 229-235

20. Ministry of Food and Drug Safety (1997) Korea food code. Ministry of Health and Welfare, Osong, Korea, p 507-510

21. Park BY, Yoon KY (2018) Conditions for hydrolysis of perilla seed meal protein for producing hydrolysates and ultrafiltered peptides and their antioxidant activity. Korean J Food Preserv, 25, 605-612
22. Jeoung YK, Kim JH, Baek IS, Kang YJ, Chi JH (2017) Effect of schizandra berry dregs and rice bran treatment on $\gamma$-aminobutyric acid (GABA) content enhancement in Pleurotus ostreatus. J. Mushrooms, 15, 88-93

23. Sawai Y, Konomi K, Odaka Y, Yoshitomi H, Yamaguchi Y, Miyama D (1999) Contents of $\gamma$-aminobutyric acid in stem of anaerobic incubated tea shoot. Nippon Shokuhin Kagaku Kogaku Kaishi, 46, 274-277

24. Pyo YH (2008) Effect of Monascus-fermentation on the content of GABA and free amino acids in soybean. $\mathrm{J}$ Korean Soc Food Sci Nutr, 37, 1208-1213

25. Jeon G, Lee MY, Yoon J, Jang S, Jung M, Jung HS, Lee J (2010) Effects of heat treatment and selected medicinal plant extracts on GABA content after germination. J Korean Soc Food Sci Nutr, 39, 154-158 